\title{
Phytoprotection
}

\section{Relative susceptibility of five strawberry cultivars to Meloidogyne hapla under three soil water deficit levels}

\section{S. Khanizadeh, G. Bélair et M.J. Lareau}

Volume 75, numéro 3, 1994

URI : https://id.erudit.org/iderudit/706060ar

DOI : https://doi.org/10.7202/706060ar

Aller au sommaire du numéro

\section{Éditeur(s)}

Société de protection des plantes du Québec (SPPQ)l

\section{ISSN}

0031-9511 (imprimé)

1710-1603 (numérique)

Découvrir la revue

\section{Citer cet article}

Khanizadeh, S., Bélair, G. \& Lareau, M. (1994). Relative susceptibility of five strawberry cultivars to Meloidogyne hapla under three soil water deficit levels. Phytoprotection, 75(3), 133-137. https://doi.org/10.7202/706060ar
Résumé de l'article

La sensibilité relative de cinq cultivars de fraisier au nematode des nodosités, Meloidogyne hapla, a été évaluée à trois niveaux de déficit hydrique du sol et à trois densités de population du nematode. 'Bounty' s'est avéré le cultivar le plus sensible et 'Glooscap' le moins sensible au M. hapla. Le déficit hydrique du sol, en pourcentage, a eu un effet linéaire positif sur le nombre de nodules présents sur les racines de fraisier, la production d'oeufs et le nombre de larves du $M$. hapla dans le sol, indépendamment du cultivar. Les différentes densités de population du nematode n'ont pas influencé le nombre de grappes florales, de stolons, et de collets produits par les plants de fraisier. La population initiale du M. hapla a eu un effet quadratique sur le nombre de nodules et sur le nombre de larves du $M$. hapla dans le sol, mais a eu un effet linéaire positif sur le nombre d'oeufs pondus. La nuisibilité de cette espèce de nematode sur les rendements totaux du fraisier et la grosseur des fruits est actuellement mal connue et nécessitera des études complémentaires. 


\title{
Relative susceptibility of five strawberry cultivars to Meloidogyne hapla under three soil water deficit levels
}

\author{
Shahrokh Khanizadeh ${ }^{1,2}$, Guy Bélair ${ }^{2}$, and Michel J. Lareau²
}

Received 1993-12-20; accepted 1995-01-13

The relative susceptibility of five strawberry (Fragaria $\mathrm{x}$ ananassa Duch.) cultivars to the root-knot nematode (Meloidogyne hapla) was tested under three different soil water deficit levels and three nematode densities. 'Bounty' was the most susceptible cultivar and 'Glooscap' the least susceptible for parasitism by $M$. hapla. Percent water deficit had a positive linear effect on the number of galls on strawberry roots, and on egg production and number of $M$. hapla larvae in the soil, regardless of cultivar type. Different population densities of the nematode had no effect on the final number of strawberry flower clusters, stolons and crowns. The initial $M$. hapla population had a quadratic effect on the number of galls on strawberry roots and on the number of larvae in the soil, but had a positive linear effect on $M$. hapla egg production. The harmfulness of this species to strawberry total yield and fruit size is questionable and requires further investigation.

Khanizadeh, S., G. Bélair et M.J. Lareau. 1994. Sensibilité relative de cinq cultivars de fraisier au Meloidogyne hapla sous trois niveaux de déficit hydrique du sol. PHYTOPROTECTION 75: 133-137.

La sensibilité relative de cinq cultivars de fraisier au nématode des nodosités, Meloidogyne hapla, a été évaluée à trois niveaux de déficit hydrique du sol et à trois densités de population du nématode. 'Bounty' s'est avéré le cultivar le plus sensible et 'Glooscap' le moins sensible au M. hapla. Le déficit hydrique du sol, en pourcentage, a eu un effet linéaire positif sur le nombre de nodules présents sur les racines de fraisier, la production d'oeufs et le nombre de larves du $M$. hapla dans le sol, indépendamment du cultivar. Les différentes densités de population du nématode $n^{\prime}$ ont pas influencé le nombre de grappes florales, de stolons, et de collets produits par les plants de fraisier. La population initiale du M. hapla a eu un effet quadratique sur le nombre de nodules et sur le nombre de larves du $M$. hapla dans le sol, mais a eu un effet linéaire positif sur le nombre d'oeufs pondus. La nuisibilité de cette espèce de nématode sur les rendements totaux du fraisier et la grosseur des fruits est actuellement mal connue et nécessitera des études complémentaires.

1. Department of Plant Science, Macdonald Campus of McGill University, Sainte-Anne-deBellevue, Quebec, Canada H9X 3V9

2. Agriculture and Agri-Food Canada, Horticulture research and Development Centre, 430 Gouin Blvd., Saint-Jean-sur-Richelieu, Quebec, Canada J3B 3E6. Contribution No 335/ 94.05.05R 


\section{INTRODUCTION}

The northern root-knot nematode, $\mathrm{Me}$ loidogyne hapla Chitwood, is a common plant-parasitic nematode in strawberry (Fragaria $x$ ananassa Duch.) fields (Bailey 1956; Szczygiel and Danek 1974). Under severe infestations, aboveground symptoms include wilting during hot and dry conditions, stunting and substantial yield losses. In Quebec, $M$. hapla has been observed in four major strawberry producing areas (Bélair and Khanizadeh 1994), but so far its effects on growth and yield have not been investigated. Strawberry cultivars vary in their susceptibility to parasitism by root-knot nematodes. Dickstein and Krusberg (1978) screened 33 cultivars against $M$. hapla under greenhouse conditions, and classified them as susceptible to least susceptible on the basis of a galling index on the root system. Studies by Edwards et al. (1985) and Szczygiel (1981) suggested such a rating to be misleading, because cultivars with moderate root galling showed no significant growth reduction and thus were identified as tolerant. It also appears that the resistance to $M$. hapla is dominant since strawberry seedlings obtained by crossing resistant parents showed a higher degree of resistance (Szczygiel and Danek 1974).

Many studies have reported the effect of root-knot nematodes on strawberries in different countries (Bailey 1956; Dickstein and Krusberg 1978; Edwards et al. 1985; Szczygiel and Danek 1974), but the harmfulness of this nematode to common strawberry cultivars grown in eastern Canada has not yet been investigated.

The objectives of this study were to compare the susceptibility of five widely-grown strawberry cultivars to $M$. hapla, and to determine whether soil moisture levels affect the parasitism of strawberry plants by $M$. hapla.

\section{MATERIALS AND METHODS}

Bare root certified dormant strawberry plants $(10-\mathrm{cm}$ root length with two leaves) of cultivars 'Annapolis', 'Boun- ty', 'Glooscap', 'Kent' and 'Veestar', were planted in 12-cm diam plastic pots filled with sterilized organic soil and sand (50:50; vol:vol). Plants were fertilized immediately with a solution of 10-52-10 (N-P-K), and a soluble N-P-K fertilizer (20-20-20) was applied at 2-wk intervals at a rate of $2 \mathrm{~g} \mathrm{~L}^{-1}$.

The $M$. hapla populations were obtained from the roots of tomato plants (Lycopersicon esculentum Mill. 'Rutgers') grown in a greenhouse. Infected roots containing egg masses were washed free of soil and deposited on a Baermann funnel in a mist charnber. After $24 \mathrm{~h}$, hatched second-stage juveniles were collected and observed for viability.

Two factorial experiments were performed simultaneously in a greenhouse at a constant temperature of $25 \pm 1^{\circ} \mathrm{C}$, using a randomized complete block design with six replicates. A 16 -h photoperiod was maintained during the experiment using Solux $400 \mathrm{~W}$ high pressure sodium lamps $\left(50 \mu \mathrm{mol} \mathrm{m}^{-2} \mathrm{~s}^{-1}\right)$. In the first experiment, $M$. hapla was introduced into the soil at one of three levels $\left(0,1000\right.$ and 5000 larvae pot $\left.^{-1}\right) 10$ $\mathrm{d}$ after transplanting, using a pipet. The plants were grown under these conditions for $110 \mathrm{~d}$ to study nematode population development. In the second experiment, 10,40 and $70 \%$ soil water deficits (SWD) were also applied. At the beginning of the experiment, three levels of SWD were originally achieved gravimetrically by weighing 10 pots per SWD treatment daily. After 2 wk, based on the SWD of 10 pots, the three levels were set by watering twice daily, daily, and every second day, which corresponded closely to the 10, 40 and $70 \%$ SWD treatments, respectively.

Root galls were counted $110 \mathrm{~d}$ after inoculation and eggs were counted using a previously described method (Hussey and Barker 1973). The homogeneity of variances was tested prior to combining the data for both experiments. The number of $M$. hapla larvae in the soil was estimated by processing a $100-\mathrm{cm}^{3}$ soil subsample from each pot by a modified Baermann pan method (Townshend 1963). A factorial model was used to examine the effect of 
cultivar, nematode population density, soil moisture, and their interactions on dependent variables. Percent and count data were transformed using an arcsin square root percent transformation $(\arcsin \sqrt{x / 100)}$ prior to analysis of variance (ANOVA). The ANOVA was done using the General Linear Models Procedure (GLM) of SAS (SAS Institute 1988). Contrast coefficients were calculated for non-equally spaced factors (initial inoculation: 0,1000 and 5000 larvae pot $^{-1}$ ) using a previously described method (Khanizadeh and Fanous 1992), and orthogonal polynomial contrasts were used to study the effect of soil moisture and $M$. hapla population density on measured variables. The least significant difference test (LSD) was used for means separation within the cultivars.

\section{RESULTS AND DISCUSSION}

There was no interaction among the cultivars, SWD and initial nematode concentrations, indicating that the five cultivars responded similarly to SWD and initial nematode concentrations. Therefore, each factor was examined independently.

M. hapla parasitized all cultivars, although the degree of susceptibility was different among the cultivars tested. 'Bounty' was the most susceptible cultivar, followed by 'Kent', 'Annapolis' and 'Veestar'. The least number of root galls and larvae was observed on 'Glooscap' (Table 1). Regression analysis showed no relationship between cultivar vigour (numbers of stolons, flower clusters, and crowns) and susceptibility to nematodes, indicating that vigour and susceptibility are independent.

Different levels of SWD had no effect on the number of crowns, flower clusters, and stolons on strawberry plants, but had a positive linear effect on the number of root galls and of nematode eggs and larvae per pot (Table 2). The highest SWD was most suitable for the maintenance of dense M. hapla

Table 1. Mean number of root galls, eggs and larvae of Meloidogyne hapla on five strawberry cultivars $\mathbf{3}$ mo after soil inoculation in the greenhouse

\begin{tabular}{lccr}
\hline Cultivar & $\begin{array}{c}\text { Gall } \\
\text { (number pot }\end{array}$ & $\begin{array}{c}\text { Egg } \\
\text { (number pot }\end{array}$ & $\begin{array}{c}\text { Larva } \\
\text { (number } \text { pot }^{-1} \text { ) }\end{array}$ \\
\hline Annapolis & $7 \mathrm{~b}^{\S}$ & $726 \mathrm{~b}$ & $324 \mathrm{~b}$ \\
Bounty & $138 \mathrm{a}$ & $12472 \mathrm{a}$ & $1776 \mathrm{a}$ \\
Glooscap & $0 \mathrm{~b}$ & $6 \mathrm{c}$ & $224 \mathrm{~b}$ \\
Kent & $19 \mathrm{~b}$ & $940 \mathrm{~b}$ & $635 \mathrm{~b}$ \\
Veestar & $1 \mathrm{~b}$ & $92 \mathrm{~b}$ & $7 \mathrm{~b}$ \\
\hline
\end{tabular}

\$ Means followed by the same letter within a column are not significantly different at the $5 \%$ level of significance using the LSD test.

Table 2. Mean number of root galls, eggs and larvae produced by Meloidogyne hapla in potgrown strawberry plants at three levels of soil water deficit 3 mo after soil inoculation in the greenhouse

\begin{tabular}{|c|c|c|c|}
\hline $\begin{array}{c}\text { Soil water deficit } \\
(\%)\end{array}$ & $\begin{array}{c}\text { Gall } \\
\text { (number pot }{ }^{-1} \text { ) }\end{array}$ & $\begin{array}{c}\text { Egg } \\
\text { (number pot }{ }^{-1} \text { ) }\end{array}$ & $\begin{array}{c}\text { Larva } \\
\left(\text { number pot }^{-1}\right)\end{array}$ \\
\hline 10 & 22 & 926 & 240 \\
\hline 40 & 34 & 2082 & 640 \\
\hline 70 & 44 & 5538 & 692 \\
\hline Orthogonal contrast & Linear* & Linear* & Linear* \\
\hline
\end{tabular}

\footnotetext{
* Significant at the $5 \%$ level using the $F$ test.
} 
Table 3. Mean number of root galls, eggs and larvae observed in pots of strawberry plants 3 mo after soil inoculation in the greenhouse

\begin{tabular}{cccc}
\hline $\begin{array}{c}\text { Inoculation level } \\
\left(\text { (larvae } \text { pot }^{-1}\right)\end{array}$ & $\begin{array}{c}\text { Gall } \\
\left(\text { number } \text { pot }^{-1}\right)\end{array}$ & $\begin{array}{c}\text { Egg } \\
\left(\text { number } \text { pot }^{-1}\right)\end{array}$ & $\begin{array}{c}\text { Larva } \\
\left(\text { (number }^{-1} \text { pot }^{-1}\right)\end{array}$ \\
\hline 0 & 0 & 0 & 0 \\
1000 & 36 & 2160 & 668 \\
5000 & 62 & 4998 & 908 \\
Orthogonal contrast & Quadratic $^{*}$ & Linear & Quadratic* $^{*}$ \\
\hline
\end{tabular}

* Significant at the $5 \%$ level using the $F$ test.

populations and successful reproduction (Table 2), indicating that strawberry plants grown under stress conditions (high SWD) are most susceptible to colonization by $M$. hapla. Our results corroborate those of Maas (1984), who reported that the root-knot nematodes were particularly damaging to strawberry plants during periods of summer drought, but do not agree with the results obtained by Szczygiel and Soroka (1983) who found no correlation between soil moisture levels and population densities of $M$. hapla.

The effects of initial inoculation density of $M$. hapla on the number of root galls and nematode larvae were quadratic, but the effect on egg number was linear (Table 3 ). It seems that in a $12-\mathrm{cm}$ pot, inoculum of 1000 larvae was not excessive, whereas 5000 larvae pot $^{-1}$ was sufficient to cause competition for the small root systems of the strawberry plants. Subsequently, the females that were able to invade the strawberry root system may have produced high numbers of eggs, but possibly the rate of egg maturation or viability was adversely affected by crowding. A gradual increase in the number of larvae added per pot did not proportionately increase the number of root galls and larvae produced in the pots. An examination of the strawberry cultivars in the field and an assessment of the impact of $M$. hapla on final yield and fruit size is necessary, since it has been shown that some cultivars with medium root galling responded with reduction in vegetative growth, while others with higher root galling showed no reduction in growth (Szczygiel 1981).
The results of our study indicated that parasitism and reproduction of $M$. hapla on strawberry is favoured by dry soil conditions. Although hatching of $M$. hapla eggs is not inhibited under dry soil conditions such as the wilting point, migration and infectivity of $M$. hapla was shown to be optimized when the soil is moist or near field capacity (Szczygiel and Soroka 1983).

Secondary infection caused by pathogens penetrating the root system through nematode-related lesions appears more important than direct damage caused by nematodes as demonstrated by LaMondia and Martin (1988). They found that higher nematode levels (Pratylenchus penetrans Cobb) were more effective in increasing black root rot caused by Rhizoctonia fragariae Hasain \& McKeen in field studies. The results obtained from the study identified resistant cultivars which may be useful in breeding programs. The negative effect of $M$. hapla on strawberry yield and berry size and its importance as a strawberry pest per se is questionable and requires further investigation under conditions in Quebec.

\section{REFERENCES}

Bailey, J.S. 1956. Does the root-knot nematode (Meloidogyne sp.) thrive in the roots of strawberry in Massachusetts? Plant Dis. Rep. 40: 44.

Bélair, G., and S. Khanizadeh. 1994. Distribution of plant-parasitic nematodes in strawberry and raspberry fields in Quebec. Phytoprotection 75: 101-107.

Dickstein, E.R., and L.R. Krusberg. 1978. Reaction of strawberry cultivars to the northern root-knot nematode, Meloidogyne hapla. Plant Dis. Rep. 62: 60-61. 
Edwards, W.H., R.K. Jones, and D.P. Schmitt. 1985. Host suitability and parasitism of selected strawberry cultivars by $M$. hapla and $M$. incognita. Plant Dis. 69: 40-42.

Hussey, R.S., and K.R. Barker. 1973. A comparison of methods of collecting inocula of Meloidogyne spp., including a new technique. Plant Dis. Rep. 57: 1025-1028.

Khanizadeh, S., and M.A. Fanous. 1992. Statistical Methods ${ }^{\oplus}$ : A computer program to calculate orthogonal polynomial coefficients. Hortscience 27: 367.

LaMondia, J.A., and S.B. Martin. 1988. Plant parasitic nematodes and fungi are an unhealthy alliance against strawberries. Front. Plant Sci. 40(2): 3-4.

Maas, J.L. 1984. Compendium of strawberry diseases. The American Phytopathological Society, St. Paul, Minnesota. 138 pp.

SAS Institute Inc. 1988. SAS/STAT, user's guide: release 6.03 ed. SAS Institute Inc. Cary, North Carolina. 1028 pp.
Szczygiel, A. 1981. Trials on susceptibility of strawberry cultivars to the northern rootknot nematode, Meloidogyne hapla. Fruit Sci. Rep. 8: 115-119.

Szczygiel, A., and J. Danek. 1974. Pathogenicity of three species of root parasitic nematodes to strawberry plants as related to methods of inoculation. Zesz. Probl. Postepow Nauk. Roln. 154: 133-149.

Szczygiel, A., and A. Soroka. 1983. Effect of soil moisture level on population and pathogenicity of three plant-parasitic nematodes to strawberry plants. Zesz. Probl. Postepow Nauk. Roln. 278: 105111.

Townshend, J.L. 1963. A modification and evaluation of the apparatus for the Oostenbrink direct cottonwool filter extraction method. Nematologica. 9: 106-110. 